\title{
Food security scenario, challenges, and agronomic research directions of Nepal
}

\author{
DR Bista ${ }^{1}$ LP Amgain ${ }^{2}$ and S Shrestha ${ }^{2}$ \\ ${ }^{1}$ Ministry of Agricultural Development, Kathmandu, Nepal \\ ${ }^{2}$ Institute of Agriculture and Animal Sciences, TU, Nepal
}

\begin{abstract}
The interim constitution of Nepal has mentioned "food sovereignty as fundamental right in its constituents 18.3". However, Nepal is experiencing decline in food security situation due to collision of domestic, national and international crises viz. poor agricultural growth, declined national agricultural priority, global climate change, global food crisis, and political instability. There is domination of small and marginal holders in Nepalese agriculture. Although the share of agriculture in country's GDP is decreasing, it is still 33\%, and the highest among the South Asian countries. Cereals are the most important staple food crops in Nepal and rice number one from area and production followed by maize, wheat, millets and barley. The grain-legumes and potatoes are considered the protective food crops for the maintenance of balance human nutrition in Nepal. Out of 88 countries, Nepal ranked $57^{\text {th }}$ in Global Hunger Index (GHI) with GHI value of 19.8 depicting alarming situation of hunger in different regions of the country. Since the III Five year plan (197580 ), the government of Nepal has given high priority in agriculture, focusing major approaches on promotion of integrated farming systems to address food and nutrition security. However, the food security situation is deteriorating. Adaptive measures on climate change, food distribution policy, crop and livestock insurance, subsidies on fertilizers and seeds, research and development activities on food-grain crops and bio-diversity conservation, inter agency coordination, food and seed buffer stock, and institutional capacity building would the viable options to maintain the food security in Nepal. From the rigorous study of various past research works, it can be concluded that the wider gap of several food grain crops can be reduced by system research, crop modelling, and up-scaling the use of agricultural machineries and tools.
\end{abstract}

Key words : agronomic crops, agronomic research direction, food security

\section{Introduction}

Food security prevails when all people at all times have access to sufficient, safe and nutritious food to maintain a healthy and active life (FAO, 2003). Basically, food availability, food access and food use are considered the three pillars of food security. The consideration is that all physical and economic access to food that meets people's dietary needs as well as their food preferences should be achieved by all human beings. The ever growing population of the world, their changes in food habits like increased demand for animal protein (grain conversion to meat), increased fuel prices (costly inputs/ transport), climate change and increased drought situations, need of grains for biofuel production and under investment in agriculture sector at the national and international levels are the main reasons of global food insecurity. In this context, food security situation of least developed countries like Nepal is not much different from the majority of countries in the world. The interim constitution of Nepal has mentioned "food sovereignty" as fundamental right in its constituents 18.3. This statement tries to protect people from the negative consequences of increasing food insecurity, unequal food distribution and no access to food. 
Nepal is predominantly an agrarian country, wherein $65.7 \%$ of the population is engaged in agriculture (MoAC, 2009). Agriculture, in Nepal, is dominated by small and marginal holdings, which constitute $92.4 \%$ of operational holding and $68.6 \%$ of operated area. The average size of holding is 0.8 ha (CBS, 2004). Although the share of agriculture in the GDP is around 34\%, this is highest among the South Asian counties. The percentage of population live below the poverty line is 31 . Nepal is one of the least developed countries and among 182 countries it ranked $144^{\text {th }}$ in Human Development Index (UNDP, 2009). Nepal has experienced sharp decline in food security situation in recent years especially after mid 1990's (Table 1). Out of 88 countries, Nepal ranked $57^{\text {th }}$ in Global Hunger Index (GHI) with GHI value of 19.8 depicting alarming situation of hunger in different regions of the country (IFPRI, 2009). There are localized food shortages in different parts of the country and hunger problem is severe in some parts of the far and mid western mountainous districts. The graph presented in Figure 1 shows the food security situation in Nepal from 1990/91 to $2008 / 09$. This Figure shows the negative food balance for most of the years in Nepal.

Table 1. Global Hunger Index (GHI) of five South Asian countries

\begin{tabular}{lcccl}
\hline Countries & GHI 1990 & GHI 2009 & \% Reduction & Remarks \\
\hline Nepal & 27.6 & 19.8 & 28.26 & Serious \\
India & 31.7 & 23.9 & 24.6 & Alarming \\
Pakistan & 24.7 & 21 & 14.97 & Alarming \\
Bangladesh & 35.9 & 24.7 & 31.19 & Alarming \\
Sri Lanka & 21.1 & 13.7 & 35.07 & Serious \\
\hline
\end{tabular}

(Source. IFPRI, 2009)

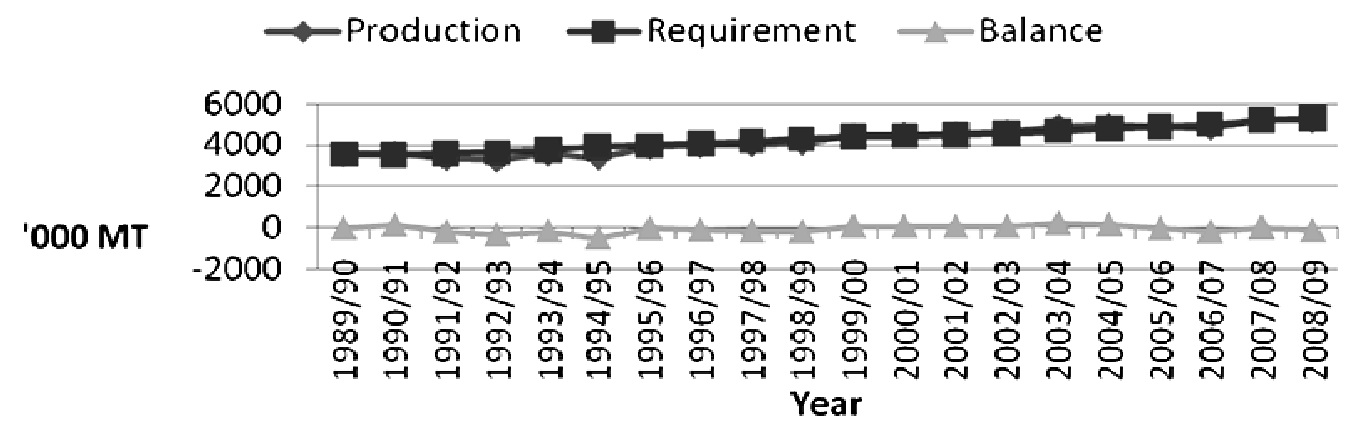

(Source. MoAC, 2009)

Figure 1. Production and requirement of edible cereals in Nepal

Although the food security situation is not good in Nepal, there are ample opportunities to improve it. Nepal has rich climatic variability having sub-tropical to alpine climate due to high altitude range. Therefore, the country is suitable to produce various food crops, pulses, oilseeds, fruit, and vegetables. Out of 14.71 million hectares of the total geographical area, 4.21 million hectares is cultivable land in Nepal. Out of this, only 3.0 million hectares has been cultivated (71\% of the total cultivable land). Out of the total cultivated land, $38.66 \%$ (1.16 million hectares) is irrigated and the rest is rainfed (MoAC, 2009). 
Cereals are the most important crops of Nepal sharing $49.41 \%$ in the AGDP. Among cereals, rice is the dominant crop sharing $20.75 \%$ of the total AGDP (MoAC, 2009). After rice, maize, wheat, potato, millet and barley are the important food crops of Nepal. From these discussions, it can be concluded that the maintaining food security situation through domestic production is difficult now. Also, there is immense role of cereals in fulfilling the food requirements of the country.

\section{Methodology}

This study aimed to find out the status of food grain production, the causes of low production, and the mitigation strategies of food insecurity situation in Nepal by analysing FAO data base, searching internet, and reviewing various literature. Ranking of major internal and external challenges of low agricultural production and food security is done. According to this, small farm size, poor irrigation facilities, declining investment in agriculture, changing behaviors of consumers towards the commodity choice, low agriculture production and yield, reluctance of youths towards agriculture, and climate change have been ranked in sequence. Research works done at the NARC, IAAS and various international development institutions have been reviewed to gather the data for this research.

\section{Results and discussion}

\section{Challenges of food security situation in Nepal}

Over the past 8 years, production of cereals increased by only $5 \%$ whereas consumption requirement increased by more than $20 \%$ in Nepal (WFP, 2009). Terai, the "bread basket of Nepal" produces surplus food, while Hill and Mountain produce less than their regional requirements. This is mainly due to low level of input use.

Fertilizer and irrigation were the two major production inputs identified by APROSC and JMA Inc (1995). In comparison to other South Asian countries, the use of fertilizers and irrigated area of Nepal is very low (Table 2). As shown in the Table 2, application of fertilizer per unit area is lowest in Nepal (26.46 kg/ha in 2009). Similarly, the percentage of irrigated agricultural land is second lowest $(27.42 \%$ in 2010) among the countries. The main reason behind the low use of fertilizer is its availability and high prices although the government is providing subsidy on chemical and organic fertilizers to increase crop productivity so as to improve food security situation. Removing subsidy on shallow tube wells could not increase the irrigated area as envisaged in the APP.

Table 2. Fertilizer use and irrigated area of five South Asian countries

\begin{tabular}{lccc|ccc}
\hline \multirow{2}{*}{ Countries } & \multicolumn{3}{c|}{ Fertilizer use (kg/ha) } & \multicolumn{3}{c}{ Irrigated area (\% of agricultural } \\
& 1980 & 2000 & 2009 & 1980 & 2000 & 2010 \\
\cline { 2 - 7 } & 10 & 55.38 & 26.46 & 12.41 & 26.86 & 27.42 \\
\hline Nepal & 35 & 107 & 147 & 22.64 & 33.10 & 37.12 \\
India & 46 & 166 & 176 & 15.21 & 44.54 & 56.05 \\
Bangladesh & 53 & 136 & 166 & 58.02 & 67.12 & 76.51 \\
Pakistan & 180 & 277 & 101 & 19.45 & 24.25 & 21.75 \\
Sri Lanka & \multicolumn{3}{c}{ (Source. Directorate of Economics and Statistics, 2008) }
\end{tabular}




\section{Low productivity of major cereals}

The data provided in Table 3 compared the existing yield level of Nepal with the best performing country in the region and yield gaps of rice, maize, wheat, millet, barley, and pulses. Yield level of neither of the crop is higher in Nepal than other countries. The yield gap of rice, maize, and barley is higher than $1.0 \mathrm{t} / \mathrm{ha}$ between Nepal and the best performing country.

Table 3. Yield gap between Nepal and the best performing country in South Asia (2011)

\begin{tabular}{lccc}
\hline \multicolumn{1}{c}{ Crops } & Best Performing Country (t/ha) & Nepal (t/ha) & Gap (t/ha) \\
\hline Rice & Bangladesh (4.21) & 2.98 & 1.23 \\
Maize & Bangladesh (6.15) & 2.28 & 3.87 \\
Wheat & India (2.98) & 2.27 & 0.71 \\
Millet & Bhutan (1.27) & 1.12 & 0.15 \\
Barley & India (2.35) & 1.06 & 1.29 \\
Pulses & Bangladesh (0.93) & 0.91 & 0.02 \\
\hline
\end{tabular}

\section{Negative consequences of climate change}

Global ambient temperature in South Asia including Nepal is increasing with an average rate of $0.06^{\circ} \mathrm{C}$ per decade between 1977 and 2000 and it is estimated to be increased more in the future. This is affecting the whole crop production throughout the country. Moreover, in the past 3 years, Nepal suffered two of the worst winter droughts, which resulted in decreased national crop production in 2006/07 and 2008/09 (MoAC/ WFP/FAO, 2009).

There was reduction in yield of wheat by $14.5 \%$ and barley by $17.3 \%$ in $2008 / 09$. However, crop losses were more than $50 \%$ and $46 \%$ respectively in the hill and mountain districts of mid and far western development regions. MoAC/WFP/FAO (2009) estimated that 3.4 million people were highly to severely food insecure due to winter drought in 2008/09. Melting of Himalayan glaciers is reportedly thinning by $0.3-1 \mathrm{~m} / \mathrm{year}$. This leads to increased risk of natural disaster in the form of mass flooding due to the overflow from glacial lakes (IPCC, 2007).

\section{Less government expenditure and poor agricultural growth}

Over the years, government's priority shifted from agriculture to other sectors. As a result, government allocation was declining in agriculture (Figure 3a). This has an impact on agricultural GDP growth rate, which was poor and remained less than five percent for several years (Figure 2a and $2 b$ ). This reduced the overall GDP growth rate and was lowest amongst the South Asian countries from 2007 to 2009 (Figure 3b). 


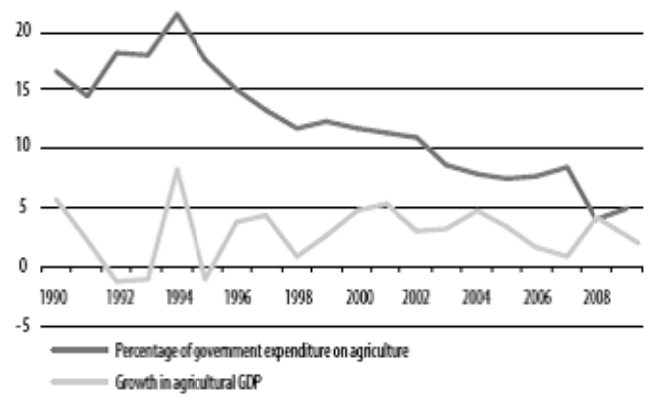

Figure 2a. Government expenditure and agricultural growth

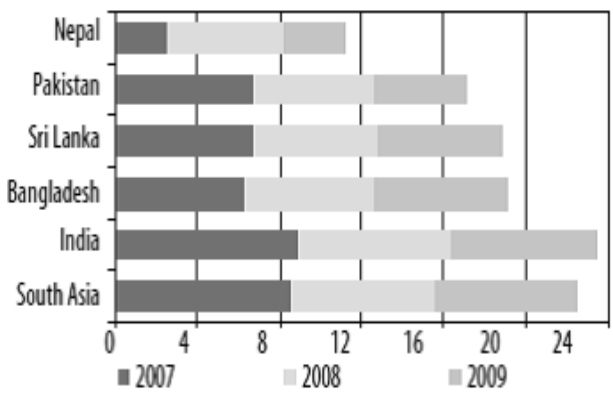

(Source. WFP, 2009a)

Figure 2b. Comparison of GDP growth rate between South Asian countries

\section{Food price rise in domestic and global market}

Nepal was hit hard by global food crisis and price inflation, which was $17.1 \%$ in March 2009. In January 2008, urgent food assistance was required for 1.3 million people. The number of people requiring urgent food assistance went up to 2.7 million by December 2008. In the same year, 3.7 million people were estimated to be food insecure (WFP, 2009a). Crop failure and rising global food prices contributed increasing food insecurity situation in Nepal (FAO, 2008). Sharp rise in prices of several food items was experienced in Nepal from April 2008 to October 2009. In this duration, prices of lentil and black gram, the most widely consumed pulses in Nepal, increased by $67 \%$ and $36 \%$, respectively. Similarly, prices of rice, wheat flour and potatoes increased by $24 \%$, $17 \%$, and $116 \%$ respectively (WFP, 2009).

\section{Coordination among agencies involved in agriculture}

There are three major stakeholders involved in agricultural development of Nepal. Lack of coordination is experienced between Nepal Agricultural Research Council (NARC), which is mandated to conduct agricultural research, Department of Agriculture (DoA) mandated to conduct extension work, and Institute of Agriculture and Animal Sciences (IAAS) under Tribhuvan University (TU) mandated primarily for teaching and secondarily for research and extension. This coordination gap is also contributing to the slow growth of agriculture sector in the country. In Nepal, CGIAR organizations, and several INGOs and NGOs are the important source of funding for agricultural research. Due to coordination gap between these organizations, only a few need base research programmes were conducted in the past and recommendations of these research works were not properly incorporated in performing development activities.

\section{Initiatives taken by the Government of Nepal to improve food security situation}

In order to increase crop productivity and maintain food security situation, the Nepalese government is inspiring agricultural development workers and scientists (DOA, NARC, universities, and $\mathrm{NGO} / \mathrm{s} / \mathrm{INGO} / \mathrm{s}$ ) to increase crop productivity and reduce the yield gap. To ensure this, the 46 
government is emphasizing on crop and livestock insurance, subsidies in fertilizers and seeds, more research and development programmes on food-grain crops, bio-diversity conservation, climate change measures, food and seed buffer stock, and appropriate food distribution policy. The realization is that the wide yield gap of several food grain crops can be reduced by system research, crop modelling, and the introduction of appropriate farm machinery and tools.

\section{Accomplishment of agronomical research at Nepal Agriculture Research Council}

The majority of cultivated areas (71\%) are rainfed and risky from erratic rainfall in Nepal. Most of the rice varieties developed by NARC have yield potential of $4-5$ ton/ha, but large gap exists between research station and farmers' field. In order to strengthen synergism among disciplines, the National Rice Research Program (NRRP) has started strategic research for accelerating rice breeding program by conducting conventional breeding in combination with molecular tools, resource conservation technologies, integrated disease and pest management system, integrated plant nutrient management system, post harvest technology and value addition, socioeconomic and policy research, participatory technology assessment and transfer, and human resource development (NRRP, 2009). The commodity research programs throughout the country under NARC are preparing to boost up crop production by developing site-specific, advanced, and affordable agronomic technologies.

The role of NMRP is vital to develop different maize-based technologies and maintain the food security situation in Nepal. The maize + kidney bean intercropping recorded the highest marginal rate of returns (1.48) and cost.benefit ratio (1.60). Arun-4 with spacing of $75 \times 15 \mathrm{~cm}$ gave the highest grain yield (4.68 t/ha). Hybrid between RML-2 and NML-2 with $60 \times 20 \mathrm{~cm}$ spacing yielded the highest grain yield (8945 kg/ha). Sulphur@ $40 \mathrm{~kg} / \mathrm{ha}+5$ ton lime/ha recorded the highest grain yield $(6.86 \mathrm{t} / \mathrm{ha})$ as against no sulphur + no lime treatment $(2.90 \mathrm{t} / \mathrm{ha})$. Arun-1, with compost $10 \mathrm{t}+120.60 .40 \mathrm{~kg} \mathrm{NPK} / \mathrm{ha}$ gave the highest grain yield $(8.9 \mathrm{t} / \mathrm{ha})$. The yield of Rampur Composite was the highest (5.8 t/ha) when $120.60 .40 \mathrm{~kg}$ NPK/ha along with $5 \mathrm{~kg} \mathrm{~B}+5 \mathrm{~kg} \mathrm{Zn+0.5}$ $\mathrm{kg} \mathrm{Mo}+20 \mathrm{~kg} \mathrm{~S}+12 \mathrm{~kg} \mathrm{Mn} / \mathrm{ha}$ was applied in soil. The bed planting method recorded significantly higher grain yield $(4776.04 \mathrm{~kg} / \mathrm{ha})$ than the farmers' practice $(4579.97 \mathrm{~kg} / \mathrm{ha})$ and zero tillage $(4337.37 \mathrm{~kg} / \mathrm{ha})$. The bed planting (FIRB) generated about $10.52 \%$ higher net returns over farmers' practice (NMRP, 2009).

Wheat requirement is estimated to be 1,634,000 t by 2015 in Nepal and this needs an annual growth rate of $2.23 \%$ in wheat production. The total requirement must come either from increased productivity or by bringing rice-fallow into rice-wheat system. The sustainable management of the rice-wheat system along with the development and dissemination of high yielding, disease resistant and location specific wheat varieties should get top priority to increase the productivity of both wheat and rice. The NWRP in collaboration with rice-wheat consortium came up with effective technologies in wheat crop establishment and farm mechanization to reduce the total cost of wheat production. Resource conservation technologies (RCTs), integrated nutrient management (INM) and soil fertility management are the major themes of priority research at present. Up-scaling of these useful technologies will be at the top priority in future as well (NWRP, 2012). 
The research works conducted by various national commodity programmes are focussed towards overcoming the agronomic challenges. Nepal Agriculture Research Council has set up following strategies to overcome those challenges.

\section{Future strategies of NARC on major food crops of Nepal}

- Development of drought tolerant, disease and insect resistant OPVs suitable for rainfed condition.

- Development and dissemination of profitable cereal crop based intercropping technologies.

- Expansion and strengthen CBSP for the production and marketing of good quality seeds.

- Promotion and popularization of recently released maize varieties including a QPM variety to overcome the malnutrition problem of hills.

- Popularization of manual and bullock drawn farm tools and implements to cope up the labour shortage and reduce women' drudgery.

- Up-scaling of conservation agriculture (residue incorporation, mulching, and zero tillage).

- Strengthen the linkages, collaboration and coordination with research and development partners.

\section{Accomplishment of agronomical research at Institute of Agriculture and Animal Sciences}

Various research works have been completed by professors and students of the IAAS. Among them, studies on yield gap and climate change are important.

\section{Yield gap analysis of major crops}

The potential yield and the actual yield of different varieties of crops at IAAS station and farmers' field are presented in Table 4. The cursory view on this table shows that the actual yield of all observed crops in Chitwan condition (both at IAAS station and farmers' field) were lower than the potential yield. On this basis, the yield gaps of different crops are calculated.

The common rice cultivar Masuli, which is grown extensively in Chitwan, has the yield potential of $5.5 \mathrm{t} / \mathrm{ha}$ and the maize cultivar 'Rampur Composite' has the yield potential of $4.4 \mathrm{t} / \mathrm{ha}$ (MoAC 2005). NL-297, UP-262, BL-1473 are the popular wheat varieties in Chitwan and these varieties have an average yield potential of $5.0 \mathrm{t} / \mathrm{ha}$ (MoAC, 2005). The potential yield of rapeseed and mustard is 1.1 $\mathrm{t} / \mathrm{ha}$ and is quite low as most of the varieties grown are local, and are highly susceptible to Alternaria blight and aphids. More emphasis is needed to identify the suitable varieties of rapeseed and mustard as they contribute to about $90 \%$ of the oil requirement of Nepal. The popular potato cultivars, such as Desiree, Cardinal, and Kufri Jyoti have the yield potential of 20.0 t/ha (MOAC, 2008/09), but there is a big gap between the potential yield and the yield at farmers' field. Same is the case with the grain legumes, such as soybean and lentil. 
Table 4. Yields and yield gaps ( $t / h a)$ of major crops in Chitwan, Nepal

\begin{tabular}{lcccccc}
\hline Crops & $\begin{array}{l}\text { Potential } \\
\text { yield (A) }\end{array}$ & $\begin{array}{l}\text { IAAS } \\
\text { Station } \\
\text { yield (B) }\end{array}$ & $\begin{array}{l}\text { Farmers' } \\
\text { yield (C) }\end{array}$ & $\begin{array}{l}\text { Yield gap 1 } \\
\text { (A-B) }\end{array}$ & $\begin{array}{l}\text { Yield gap } \\
\text { 2 (B-C) }\end{array}$ & $\begin{array}{l}\text { Yield gap } \\
\text { 3 (A-C) }\end{array}$ \\
\hline Rice & 5.50 & 3.40 & 2.74 & 2.1 & 0.66 & 2.76 \\
Maize & 4.40 & 3.30 & 1.82 & 1.1 & 1.48 & 2.58 \\
Wheat & 5.00 & 3.50 & 1.88 & 1.5 & 1.62 & 3.12 \\
Finger millet & 3.30 & 2.20 & 1.09 & 1.1 & 1.11 & 2.21 \\
Rapeseed and & 1.10 & 1.00 & 0.71 & 0.1 & 0.29 & 0.39 \\
mustard & & & & & & \\
Soybean & 2.00 & 1.50 & 0.85 & 0.5 & 0.65 & 1.15 \\
Lentil & 2.50 & 1.75 & 0.82 & 0.75 & 0.93 & 1.68 \\
Potato & 20.0 & 16.5 & 10.90 & 3.5 & 5.6 & 9.1 \\
\hline
\end{tabular}

(Source. Amgain and Timsina, 2005)

The yields of rice, maize and potato are increasing steadily in Nepal, but the yields of wheat, rapeseed, mustard and lentil are almost stagnant over time. The gaps between the potential and farmers' field yields (yield gap 3) of major crops are 2.76 t/ha for rice, $2.58 \mathrm{t} / \mathrm{ha}$ for maize, $3.12 \mathrm{t} / \mathrm{ha}$ for wheat and $9.1 \mathrm{t} / \mathrm{ha}$ for potato. The yield gap is low $(0.39 \mathrm{t} / \mathrm{ha})$ for rapeseed and mustard, but their potential yields are also low. For rice, the yield gap between potential and research station yields (yield gap 1) is larger than that for maize and wheat. Hence, improved agronomical research on rice varieties and crop and soil management would be required to reduce this gap. The gap between research station and farmers' field yields (yield gap 2) is larger for wheat than for rice and maize, suggesting the management of wheat field at the farmers' level is poor. Therefore, extension of recommended technologies on crop management and their adoption by farmers would help increase farmers' yields and reduce the gap. These results suggest that there is immense scope to raise yields of major cereals, potatoes, pulses, and oilseeds in farmers' fields.

\section{Climate change studies}

The results of simulation modelling studies on rice and maize crops by using DSSAT crop model in the sub-tropical environment indicated that although hybrids are high yielders, they are more sensitive to adverse effects of climate change than open pollinated ones (Table 5 and 6 ). 
Table 5. Simulation of rice yield with changing climatic scenarios at IAAS, Chitwan, Nepal

\begin{tabular}{|c|c|c|c|c|c|c|c|}
\hline \multicolumn{4}{|c|}{ Scenarios } & \multicolumn{4}{|c|}{ Crop yield and biology } \\
\hline $\begin{array}{c}\text { Min temp } \\
\left({ }^{\circ} \mathrm{C}\right)\end{array}$ & $\begin{array}{c}\text { Max } \\
\text { temp } \\
\left({ }^{\circ} \mathrm{C}\right)\end{array}$ & $\begin{array}{c}\mathrm{CO}_{2} \text { conc. } \\
\text { (ppm) }\end{array}$ & $\begin{array}{c}\text { Solar } \\
\text { radiation } \\
\left(\mathrm{MJ} / \mathrm{m}^{2} / \text { day }\right)\end{array}$ & Crop varieties & $\begin{array}{l}\text { Growth } \\
\text { duration } \\
\text { (days) }\end{array}$ & $\begin{array}{c}\text { Simulated } \\
\text { yield } \\
(\mathrm{kg} / \mathrm{ha})\end{array}$ & $\begin{array}{l}\% \text { yield } \\
\text { change }\end{array}$ \\
\hline \multirow{3}{*}{\multicolumn{4}{|c|}{ Standard model parameters }} & Prithvi & 104 & 5754 & - \\
\hline & & & & Masuli & 134 & 3892 & - \\
\hline & & & & Sunaulo Sugandha & 145 & 4468 & - \\
\hline \multirow[t]{3}{*}{+4} & \multirow[t]{3}{*}{+4} & \multirow[t]{3}{*}{0} & \multirow[t]{3}{*}{0} & Prithvi & 96 & 2310 & -77 \\
\hline & & & & Masuli & 111 & 2310 & -41 \\
\hline & & & & Sunaulo Sugandha & 117 & 2928 & -44 \\
\hline \multirow[t]{3}{*}{+4} & \multirow[t]{3}{*}{+4} & \multirow[t]{3}{*}{+20} & \multirow[t]{3}{*}{-1} & Prithvi & 86 & 1548 & -73 \\
\hline & & & & Masuli & 111 & 2104 & -46 \\
\hline & & & & Sunaulo Sugandha & 117 & 2686 & -40 \\
\hline \multirow[t]{3}{*}{-4} & \multirow[t]{3}{*}{-4} & \multirow[t]{3}{*}{+20} & \multirow[t]{3}{*}{+1} & Prithvi & 139 & 9342 & +62 \\
\hline & & & & Masuli & 212 & 5486 & +41 \\
\hline & & & & Sunaulo Sugandha & 226 & 6385 & +42 \\
\hline
\end{tabular}

(Source. Lamsal and Amgain, 2010)

Note. The observed days of antheis, physiological maturity days, and yields ( $\mathrm{kg} / \mathrm{ha}$ ) for rice cultivar Prithvi was 74, 101 and 5754; for Masuli was 103, 134 and 3852; and for Sunaulo Sugandha was 112,145 and 4468, respectively.

Table 6. Simulation of maize yield with changing climatic scenarios at IAAS Rampur, Nepal

\begin{tabular}{|c|c|c|c|c|c|c|c|}
\hline \multicolumn{4}{|c|}{ Scenarios } & \multicolumn{4}{|c|}{ Crop yield and biology } \\
\hline $\begin{array}{l}\text { Min } \\
\text { temp } \\
\left({ }^{\circ} \mathrm{C}\right)\end{array}$ & $\begin{array}{l}\text { Max } \\
\text { temp } \\
\left({ }^{\circ} \mathrm{C}\right)\end{array}$ & $\begin{array}{l}\mathrm{CO}_{2} \\
\text { conc. } \\
\text { (ppm) }\end{array}$ & $\begin{array}{c}\text { Solar } \\
\text { radiation } \\
\left(\mathrm{MJ} / \mathrm{m}^{2} / \text { day }\right)\end{array}$ & Crop varieties & $\begin{array}{c}\text { Growth } \\
\text { duration } \\
\text { (days) }\end{array}$ & $\begin{array}{c}\text { Simulated } \\
\text { yield } \\
(\mathrm{kg} / \mathrm{ha})\end{array}$ & $\begin{array}{l}\% \text { yield } \\
\text { change }\end{array}$ \\
\hline \multirow{3}{*}{\multicolumn{3}{|c|}{ Standard model parameters }} & & R Composite & 109 & 4357 & - \\
\hline & & & & Upahar & 112 & 4868 & - \\
\hline & & & & Arun-4 & 100 & 3841 & - \\
\hline \multirow[t]{3}{*}{+4} & +4 & 0 & 0 & R Composite & 96 & 3809 & -13.5 \\
\hline & & & & Upahar & 98 & 3624 & -24 \\
\hline & & & & Arun-4 & 88 & 3068 & -25 \\
\hline \multirow[t]{3}{*}{+4} & +4 & +20 & -1 & R Composite & 96 & 3373 & -22 \\
\hline & & & & Upahar & 98 & 3300 & -34 \\
\hline & & & & Arun-4 & 88 & 2843 & -26 \\
\hline \multirow[t]{3}{*}{-4} & -4 & +20 & +1 & R Composite & 128 & 6491 & +49 \\
\hline & & & & Upahar & 130 & 6103 & +25 \\
\hline & & & & Arun-4 & 120 & 5525 & +44 \\
\hline
\end{tabular}

Note. R Composite - Rampur Composite. The observed days of antheis, physiological maturity days, and yields (kg/ha) for maize cultivar Rampur Composite was 68, 109 and 4552; for Upahar was 70, 112 and 5052; and for Arun-4 was 63, 100 and 4052, respectively. 
The study on the effects of global climate change in Nepal indicated that the increased temperature and concentration of $\mathrm{CO}_{2}$ gas would be harmful to both rice and maize crops to reduce their yield because of shortening crop duration and other effects on the formation of net assimilates. Hence, the adaptive measures would be required to minimize this yield gap in field crops.

\section{Accomplishment of agronomic research by non-governmental organizations in Nepal}

The seed production activities based on the direct participation of farmers are considered viable option to increase the seed supply and sustain the productivity level (CIMMYT Nepal, 2009). The HMRP programs on participatory varietal development, hill maize enhancement, and various social and capacity building are the key activities to increase maize productivity at the farmers' level.

\section{Recommendations for improving the food security situation in Nepal}

Nepal has the prospect of maintaining food security due to the availability of ecological and biological diversity. The increasing productivity of food grains, proper utilization of agrobiodiversity, agricultural intensification and mechanization, land utilization, community mobilization (e.g. community based food and seed banking program), and infrastructure development (road, irrigation, etc) will help to increase food grain production. The integration of all afore-mentioned approaches is urgently felt to ensure food security and food sovereignty at individual, household, regional and national level. Only the ensured functional coordination between concerned agencies and the institutional capacity building for food security right from the central to local level can ensure availability and access to food. From the rigorous study of various research works carried out in the past, it could be concluded that the wider gap of several food grain crops can be reduced by system research and crop modelling approach. Keeping top priority to agriculture, adapting measures in climate change, following appropriate food distribution policy, insurance of crops and subsidies in fertilizers, research and development activities on food-grain crops and bio-diversity conservation, formalizing inter-agencies coordination, food and seed bufferstock, institutional capacity building would the viable options to maintain the food security situation. The regional imbalance of food security in Nepal could be narrowed down by improving the yield gap.

\section{References}

Amgain, LP and J Timsina. 2005. Crop and cropping systems research at IAAS Rampur Chitwan. A review. J Inst. Agric. Anim. Sci. 26. 1-22.

APROSC and JMA Inc. 1995. Agriculture Perspective Plan. Government of Nepal.

Bhusal, TN, LP Amgain and NR Devkota. 2009. Evaluation of CSM-CERES-Maize model and sensitivity analysis of open pollinated varieties of maize at Rampur Chitwan. J Inst. Agric. Anim. Sci. 30. 63-72.

CBS (Central Bureau of Statistics). 2004. Nepal living standard survey. Government of Nepal, Kathmandu.

CBS (Central Bureau of Statistics). 2005. Poverty Trends in Nepal. Government of Nepal,.

CIMMYT (International Maize and Wheat Improvement Center) Nepal. 2009. Annual report. CIMMYT, South Asia Regional Office, Kathamandu, Nepal. 
Directorate of Economics and Statistics, 2008. Agricultural statistics at a glance. Department of Agriculture and Cooperation, Ministry of Agriculture, Government of India. http.//eands.dacnet.nic.in/At_Glance_2008.htm

FAO (Food and Agriculture Organization of United Nations). 2008. Food security indicators, Country. Nepal. FAO, Rome.

FAO (Food and Agriculture Organization of United Nations)/UNDP (United Nations Development Programme). 2003. Agricultural policy and strategy for poverty alleviation and food security. FAO, Rome.

IFPRI (International Food Policy Research Institute). 2009. Global hunger index. The challenge of hunger. the focus on financial crisis and gender Inequality. IFPRI, Washington DC.

IPCC (Inter-Governmental Panel on Climate Change). 2007. Climate change 2007. climate change impacts, adaptation and vulnerability. Summary for policy makers. IPCC, Geneva.

Lamsal, A and LP Amgain. 2010. Simulation of growth and yield of rice under varied agronomic management and changing climatic scenarios by using DSSAT ver. 4.0 Crop Model in Chitwan, Nepal. Journal of Hill Agriculture Research 1(2).26-35.

MoAC (Ministry of Agriculture and Cooperatives). 2005. Agriculture diary. Agriculture Information and Communication Centre, Hariharbhawan, Lalitpur, Nepal.

MoAC (Ministry of Agriculture and Cooperatives)/ WFP (World Food Programme) / FAO (Food and Agriculture Organization of United Nations). 2009. Winter drought in Nepal. Crop and food security assessment. MoAC/ WFP/ FAO. Kathmandu, Nepal.

MoAC (Ministry of Agriculture and Cooperatives). 2009. Selected indicators of Nepalese agriculture and population. Government of Nepal, Kathmandu.

NMRP (National Maize Research Program). 2009. Annual report. NMRP, Rampur, Chitwan, Nepal.

NRRP (National Rice Research Program). 2009. Annual report. NRRP, Hardinath, Dhanusha, Nepal.

NWRP (National Wheat Research Program). 2012. Annual report. NWRP, Bhairahawa, Ruapandehi, Nepal.

UNDP (United Nations Development Programme). 2009. United Nations Human Development Report. UNDP, Country Office, Kathmandu, Nepal.

USAID Nepal. 2008. Nepal economic growth assessment. Agriculture.

WFP (World Food Programme of United Nations). 2009. Nepal Food Security Bulletin, Issue-25, July-October, 2009. WFP, Lalitpur, Nepal.

WFP (World Food Programme of United Nations). 2009a. The cost of coping; a collision of crises and the impact of sustained food security deterioration in Nepal. WFP, Lalitpur, Nepal. 